\title{
Demand and Supply Docking Mechanism of Language Service Talents for Foreign Tourism Industry of China
}

\author{
LEI Qian-qian ${ }^{1}$, LIU Hai-yang ${ }^{1, *}$ \\ ${ }^{1}$ Chongqing Vocational Institute of Tourism, 409000 Chongqing, China \\ 1,* Corresponding Author
}

\begin{abstract}
Data of foreign tourism industry of China in recent years is analyzed and a demand-and-supply docking model is created based on a deep research of the contradictions between the supply and demand of language service talents in China's foreign tourism industry. On the whole, the demand for language service talents is in urgent with the foreign tourism market's high-speed expansion; the demand for multi-lingual language talents in the foreign tourism industry of China has been increasing, including the talents of Chinese itself as a foreign language; and the talents with combined skills of Language + Tourism $+X$ or Tourism + Language $+X$ are in short. In order to meet the demand of foreign tourism market of China for language service talents, the supply-and-demand mechanism should be firstly clarified and then integrate the following docking paths between the language talent's supply and demand. Firstly, the government should offer its policy support and make an overall planning for the cultivation of language service talents; secondly, colleges and universities at different levels should be demand-oriented to strengthen the cultivation of different types of language service talents; thirdly, foreign tourism industry and its industrial enterprises should strengthen their own ability of language talent cultivation and also their ability of serving colleges and universities supplying language talents. It is necessary to establish a Cooperation Steering Committee of industry, universities and colleges, research centers, enterprise, and the government, so as to realize the seamless connection between the talent cultivation of colleges and universities and the talent demand of enterprises.
\end{abstract}

\section{Introduction}

At present, the language service industry has become an important part of China's modern service industry and an important part of the global industrial chain. Language services involve various fields of translation, commerce, justice, education, taxation, library, bank, hospital, aviation, hotel, catering, tourism, advertising, ethnic minorities, human-computer, special language services and body language services, etc. Before the outbreak of global epidemic of 2020-2021, global inbound tourists consistently grew, outbound tourists and the foreign market were expanding rapidly, and the overall scale of the whole foreign tourism market was also expanding. The inbound and outbound tourism market is bound to rebound when the global epidemic is effectively prevented and controlled. Besides, with the building of The Belt and Road, China's inbound and outbound tourism markets have been faced with new opportunities and challenges. However, the current supply of language service talents can not adapt to the development of foreign-related tourism market. The disjointed supply and demand of talents will inevitably affect the development of foreign tourism of China. Considering the above problems, this study analyzes the supply- demand situation of language service talents and its supply-demand mechanism in the field of foreign tourism in China. It also explores the docking path of supply-demand of language service talents in China's foreign tourism, so as to make the supply of language talents adapt to the demand of China's foreign tourism market and realize the benign and stable development of China's foreign tourism.

\section{Language Service in the Foreign Tourism Industry of China}

\subsection{A general introduction to language service}

From the perspective of economics, language is kind of products. Huang Shao-an (2012) defined language as "scarce products with economic value and industrial characteristics"[1]. Li Xian-le(2010)defined language service from the macro and micro levels as follows: from the micro level, it mainly refers to "the paid or free activities that one party provides the other party, which are mainly performed with language as main contents or by language as a main tool, and which benefit the party who receives the service"; from the macro level, it refers to "the effective allocation, planning and standardization

${ }^{*}$ Corresponding author: belindafamily88@163.com 
of language resources made by the country or government to ensure the reasonable and effective use of language by the members within their jurisdiction". [2] The language service focused in this paper is from the micro level. From the industry perspective, Guo Xiaoyong (2010) put forward that "the scope of language services involves translation and localization services, the development of language technology tools, language teaching and training, advisory services related with language, etc." [3]. Zhao Shi-ju (2012) divided the language services into six types from the perspective of the service contents: "language knowledge service, language technology service, language tool service, language use service, language rehabilitation service and language education service" ${ }^{[4]}$.

Language service industry is a collection of enterprise economic activities aiming at producing language products and meeting customers' language needs. Globally, language service industry is an active emerging industry in the era of globalization and informatization with countries and regions' more frequent and close communication which needs the support of language service industry. Guo Xiao-yong (2011) pointed out that "the rapid socialization of translation work originally subordinate to government agencies, government-affiliated enterprises and institutions, and scientific research institutions has given birth to a new industry based on translation-language service industry, including translation and localization services, research and development of language technology and auxiliary tools, translation training and multilingual information consulting, and it is an important part of China's modern service industry and an important link in the global industrial chain". ${ }^{5]}$

\subsection{A General introduction to foreign tourism industry of China}

Tourism industry covers three major markets: domestic tourism market, inbound tourism market and outbound tourism market. The foreign tourism market in this study covers two areas: inbound tourism market and outbound tourism market. As we know, tourism has become a prospective industry with its fastest development, the most earnings of foreign exchange, the widest driving range and the highest degree of openness in the world's economy. Among them, the number of global inbound tourists continues to grow, while the number of outbound tourists and the market scale are expanding rapidly.

In 1997, China put forward the basic policy of "vigorously developing inbound tourism, actively developing domestic tourism and moderately developing outbound tourism". Up to now, China's foreign tourism has made remarkable achievements in the world, which can be strongly illustrated by the data of changes of Chinese inbound and outbound tourists from 2015 to 2019, as is shown in Figure 1.

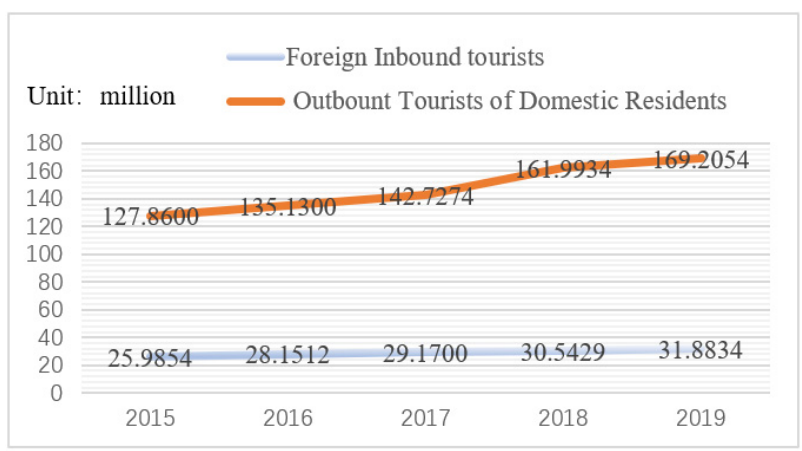

Fig. 1. Changes of Chinese inbound and outbound tourists (2016-2019)

As we know, the number of inbound and outbound tourists has slowed down during the special period of 2020-2021 affected by the breakout of global epidemic. However, the number is bound to rebound when the global epidemic is overcome, and the corresponding demand for tourism talents providing foreign language service will continue to grow.

In the following part, From the perspective of language service in the field of foreign tourism, this paper analyzes the current situation of language service talents in the foreign tourism field and the supply-anddemand mechanism of the talents.

\section{The Current Supply-and -Demand Situation of Language Service Talents in the Foreign Tourism Field of China}

\subsection{Definition of language service talents in the foreign tourism field}

Foreign tourism language service talents are high-quality compound talents who have not only basic foreign tourism language knowledge and skills, but also broad international visions, strong cross-cultural communication ability, familiar with international economic operation rules and laws and regulations, and strong tourism service and management skills.

Relevant posts for the foreign tourism language service talents include foreign tour guides of major domestic and international travel agencies; interpreters of scenic spots; foreign tourism service and management posts of travel agencies, scenic spots and other tourism related industries; marketing planning, service and management personnel of foreign hotels; reception, service and management personnel and translation position of government-affiliated major enterprises and institutions, etc.

In terms of ability, foreign tourism language service talents should not only have strong writing and speaking skills of language, but also have strong coordination ability, management ability, social ability, adaptability to tough situations, strong application ability and creativity, and can be competent for foreign-related language services in tourism agencies, scenic spots and other tourism related industries. 
From the perspective of language, the simplest way to classify foreign tourism language service talents is corresponding to single language; or it can be divided into two categories: common-language talents and noncommon language talents; or we can divide the talents into talents of foreign language and talents of Chinese as a foreign language.

\subsection{The characteristics of the supply-and- demand of language service talents in the foreign tourism field of china}

From the current situation of the supply-and-demand of language service talents in the foreign tourism field of China, we can summarize three characteristics of its tendency.

Firstly, the demand for language service talents is in urgent with the foreign tourism market's high-speed expansion. To enlarge the supply of highly qualified compound talents is essential for international tourism and is necessary for the development of the economy and society in China.

Secondly, the demand for multi-lingual language talents in the foreign tourism industry of China has been increasing, including the talents of Chinese itself as a foreign language. According to statistics, as for the official languages in the 64 countries along the routes of "the Belt and Road" construction, there are four common languages being used, English, Arabic, Russian and Chinese, while over 50 languages are the rest. It is of historical significance to cultivate qualified talents that can offer the service of the 64 countries' official languages, both common and non-common ones.

Thirdly, the talents with combined skills of Language + Tourism $+X$ or Tourism + Language $+X$ are in short. The job seekers who only know foreign language or tourism knowledge, or "language + tourism" or "tourism + language", can not meet the current demand of foreign tourism market. Foreign tourism language service talents provide language service activities in international tourism business through cross-cultural communication. First of all, with a good cultural heritage, one can not only act as the image ambassador of China's excellent national culture, but also grasp the history and culture of the source country and destination of inbound tourists. Therefore, "intercultural communication ability" is the basic foothold of compound foreign tourism service talents. Secondly, The international tourism market is one in which highly segmented industrial sectors sell products and services involving accommodation, catering, transportation, tourism and entertainment through a complex transnational distribution chain ${ }^{[6]}$. Foreign tourism talents must be familiar with the basic rules and practices of international tourism to participate in the competition of international tourism service trade. Thirdly, under the current trend of tourism digitalization, the emergence of new tourism modes such as smart tourism and "online tourism" under the epidemic situation poses a challenge to language workers in the field of foreign-related tourism, as well as an opportunity in their career. Therefore, keeping up with the pace of the times, information technology literacy and data literacy are also crucial for high-end foreign tourism language service talents.

\section{Supply-and-demand Docking Path of Foreign Tourism Language Service Talents}

\subsection{Supply-and-demand mechanism}

In order to adapt to the foreign tourism market, the supply of language service talents must explore and clarify the supply and demand mechanism of foreign tourism language service talents. There are three main channels for the supply of foreign-related tourism service talents: firstly, ordinary colleges and higher vocational colleges train foreign-related tourism service talents by offering relevant majors and courses; secondly, relevant industry associations or tourism administrative departments, star rated foreign-related tourism hotels or large-scale international travel agencies should train qualified foreign-related tourism service practitioners in the form of industry training; thirdly, the foreign-related tourism service practitioners who have changed their profession from other departments and become talents through self-study with specific industry working background or professional learning background. Combined with the above analysis of the positioning of service talents in the field of foreign-related tourism and the current situation of supply and demand, the supply and demand mechanism of foreign-related tourism language service talents is shown in Figure 2.

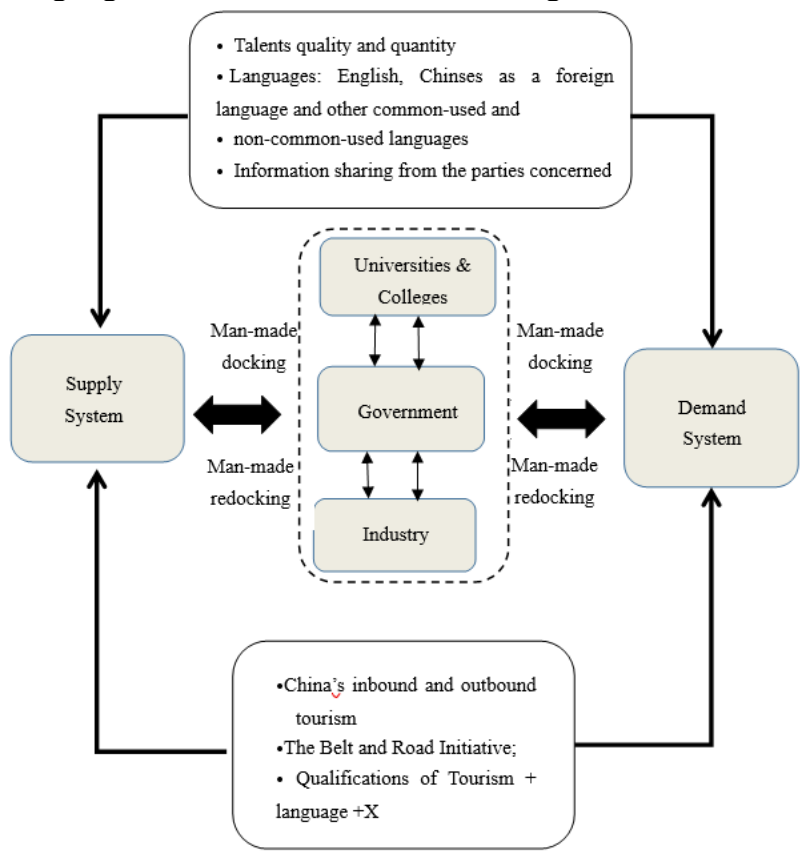

Fig. 2. Docking mechanism of supply-and-demand of language service talents in foreign tourism industry 


\subsection{Supply-and-demand docking path}

Under the supply and demand mechanism of foreign tourism language service talents, we can draw lessons from the following specific paths to realize the reasonable docking of supply and demand.

(1) The government should increase policy support for language service talents, do a good job in the training plan of language service talents in the field of foreignrelated tourism, make clear the standard positioning of talents, build an information exchange platform for the language service industry, coordinate the docking of the language service supply system and the language service demand system, and attach importance to the language use standards, language service specifications, and language service requirements in the field of foreignrelated tourism Language tools, language materials, language talent information and other open language assets, which provide support for the development of foreign tourism language service talents.

(2) Different types and levels of colleges and universities should be demand-oriented to strengthen the training of different types of language service talents. Postgraduate education can be connected with the cultivation of oriented foreign tourism language service talents, general undergraduate education can be connected with the cultivation of specialized language service talents, and higher vocational education can be connected with the cultivation of compound language talents. Colleges and universities are the core position of personnel training. No matter what type of education is, it must be market-oriented. The cultivation of foreign tourism language service talents can not simply cultivate basic language skills such as listening, speaking, reading, writing and translation. We should integrate professional knowledge and skills, pay attention to the relevant courses of "tourism + language $+X$ ", and pay attention to the cultivation of students' language big data processing ability Language consulting ability, marketing ability, project management ability and other language service ability, enhance the specialization and professionalism of personnel training.

(3) Foreign tourism enterprises should strengthen their own talent cultivation ability and the ability to serve the talent cultivation of colleges and universities. Enterprises should have foresight, pay attention to market research, focus on the demand of talent market, strengthen the training of relevant personnel in time, and improve the language service ability. The industry association should strengthen the communication with enterprises and universities, and act as a bridge between enterprise talent demand and university talent cultivation, so as to realize the sharing of teaching resources, enterprise resources and human resources between universities and enterprises, improve the quality of university talent cultivation, balance the labor force structure, and ensure the stable and orderly development of foreign-related tourism service industry.

In a word, to realize the benign adaptive development of language service talents supply and foreign tourism market, it is necessary to establish the industry, University, research, enterprise and government cooperation Steering Committee with enterprises, schools and governments as the core, so as to realize the seamless connection between university talents training and enterprise talents demand.

\section{Conclusion}

One belt, one road initiative and the "culture-go-out" strategy are facing great opportunities and challenges for China's foreign tourist market. It is of great significance to explore the supply and demand mechanism of foreignrelated tourism language service talents, integrate the docking path of talent supply and demand, and make the supply of language service talents adapt to the demand of foreign-related tourism market. It is a manifestation of the courage to face challenges, and also helps the foreign-related tourism industry to seize the development opportunities.

\section{Acknowledgments}

This work was supported by the Teaching Reform Research Project of Chongqing Vocational Institute of Tourism (YJJG2019005).

\section{References}

1. Huang Shao'an, Su Jian, Zhang Weiguo. Economics of language and chinese language industry strategy [n]. Guangming Daily, 2012-03-02 (011)

2. Li xianle. Research on language service from the perspective of language resources and language problems. Journal of Yunnan Normal University (PHILOSOPHY AND SOCIAL SCIENCES EDITION), 2010 (5): 16-21

3. Guo Xiaoyong. Development status, problems and Countermeasures of Chinese language service industry -- keynote speech at 2010 China International Language Service Industry Conference [J]. China Translation, 2010,31 (06): 34-37

4. Zhao Shiju. Definition and types of language service from the perspective of service content [J]. Journal of Beihua University (SOCIAL SCIENCE EDITION), 2012,13 (03): 4-6

5. Guo Xiaoyong. Strengthening the construction of language service industry to serve China's international communication strategy $[\mathrm{J}]$. External Communication, 2011 (07): 32-34

6. Ren Liping, He Qiaosuo, Liu Weiying, Zhang bianlan, Zhang Yong. Research on internationalization trend of foreign tourism talent development mode in China $[\mathrm{J}]$. Heilongjiang Foreign Trade and Economic Cooperation, 2009 (08): 129-130 + 142 